$\mathbb{T}$ periodica polytechnica

Social and Management Sciences $17 / 2$ (2009) 89,95

doi: 10.3311/pp.so.2009-2.05

web: []

http://www.pp.bme.hu/so

(C) Periodica Polytechnica 2009

RESEARCH ARTICLE

\title{
Web page navigation analyses for marketing management decision-making
}

László Bóta

Received 2010-01-15

\begin{abstract}
While the design principles for effective web page navigation are well-known, marketing management does not consistently require application of these principles in web page design. Furthermore, few organisations base their decisionmaking processes on thorough data analysis. On-line communication differs from traditional communication, and web page design should include adherence to ergonomic design principles and be informed by user behaviour data.
\end{abstract}

\section{Keywords}

webergonomy $\cdot$ on-line communication $\cdot$ web mining $\cdot$ preparation for decision-making $\cdot$ navigation

\section{László Bóta}

Department of Informatics, Eszterházy Károly College, H-3300, Eger, Eszterházy sqr. 1, Hungary

e-mail: botal@ektf.hu

\section{On-line marketing communication}

On-line marketing communications are part of the marketing information systems, providing data concerning the needs, preferences, and behaviour of consumers for managers and decision makers [13, p. 122]. On-line marketing communications are the sum of marketing activities, which provide data to stakeholders in an organised form about a product, brand, organisation or enterprise via on-line communication channels (Internet, intranet, extranet). The main purpose of on-line communication is to facilitate among consumers/clients, then with all stakeholders, a favourable attitude and behaviour modification [17, p. 223] towards a given organisation or enterprise. The present essay treats the term "organisation" both as profit and non-profit oriented enterprises.

All elements of the marketing communication mix can be found in on-line communication, with the exception of personal or face-to-face selling. New on-line systems such as TEEVE (Tele-immersive Environment for EVErybody) provide the visual experience of personal selling through real time placement of spatially separated real persons in a shared virtual space. However, this type of communicational approach is still in an experimental stage [2]. On-line marketing communication apparati or devices fall into three categories: Internet-based communication on the home web-pages of the organisation, communication on the web-pages of a different organisation, or webbased communications realised in a form other than web pages. Since the present essay focuses on organisational or institutional home pages, the other two categories will not be examined in detail. External web pages maintained by a different organisation are mostly used for the placement of advertisements. While this approach often carries a significant financial cost, non-paying or free communication forms, such as the uploading of brand-related data in motion picture format onto a video sharing site can be more effective. Communication schemes realised in other ways (e.g., with the help of a special program such as e-mail and IP-based telephone) are usually directed towards a pre-determined addressee.

Although the homepage of a given organisation or enterprise can provide opportunities for advertising, the promotion, public 
relations, and direct marketing, comprehensive use for all purposes is not recommended. Securing the loyalty of on-line users, leading to favourable modification of consumer behaviours, is considered an institutional priority. Consumer satisfaction with the institutional home page is indispensable for the fulfilment of this goal. Continual web page customisation based on assessment of client needs and application of pertinent research is necessary.

\subsection{Overview of the situation in Hungary}

A summary of domestic data obtained in 2007 substantiates the importance of efforts aimed at improving the efficiency of on-line communication. In both profit-oriented and non-profit sectors the level of Internet access has continuously increased. According to the Infocommunication Report in Hungary document, prepared by Bell Research, more than $96 \%$ of enterprises and businesses with a staff exceeding 10 people had Internet access, while $70 \%$ of smaller size enterprises could reach the information superhighway [12, p. 14]. Internet coverage in the institutional sector, including central and municipal governments, educational institutions, and healthcare institutions, was high, with $93 \%$ equipped with wideband Internet [10, p. 14]. Access does not translate into use, however. While the number of firms maintaining and operating their own web pages increased, the penetration level was still considered relatively low. Scarcely more than one quarter of businesses and enterprises employing at least one person created and maintained web pages for online commmunications. Only $64 \%$ of domestic enterprises had a homepage from the aggregate total of 238,000 firms. At the same time in 2007, 20\% of microbusinesses (comprising $50 \%$ of the total pool of the business category) had their own homepages, compared to $58 \%$ of firms employing more than 10 people, $70 \%$ of large enterprises, $75 \%$ of medium size enterprises, and $55 \%$ of small size enterprises. At least a third of large size enterprises operate and maintain two homepages under separate domain names, while this number in case of micro enterprises is $15 \%$ [8, p. 14]. The number of institutional web pages or homepages also increased in 2007 demonstrated by the $54 \%$ coverage rate. Homepage availability figures in case of governmentally financed institutions is $80 \%$, in locally and municipally financed institutions $70 \%$, in educational institutions $50 \%$, and $25 \%$ in the health care sector [11]. Between 2004 and 2006 the largest IT investments were made in the following three categories: the exchange of workstations (34\%), the development of local networks $(26 \%)$, and the improvement of homepages $(21 \%)$. The IT developmental data pertaining to the public sphere indicates that homepages are a crucial priority, as more than one fifth of the IT investment was allocated for this purpose [9, p. 14].

Therefore, it can be concluded that in the past years on-line communications became an integral part of the administrative operation of domestic firms, regardless of economic position or prestige. Thus, the quantity and quality related aspects of information acquisition gain priority and additional significance.
This paper is dedicated to the exploration of this topic.

\section{On-line communication dependence on navigation capability of homepage}

Theoretically, we should have access to more information on Internet users as compared to the audience and clients of traditional media. However, not all consumers use Internet, or have Internet available to them, so the rate of adequate or sufficient service is hard to establish as well.

As the distribution of data shows, the number of real consumers rapidly decreases after first access to the beginning page of a given site. Furthermore, a cross visiting rate of the more familiar sites (users visiting more than one homepage) decreases the rate of the serviced target population. Visiting or use data of a web page gives information about the respective user visits within a certain time period (day, week, month), but due to the fluctuating and dynamic nature of web pages the use or visiting data can change within a given interval. For example, an on-line advertisement can appear at a given web page at varying times, or at a pre-set hour or day [4, p. 262].

Despite present day technology's capability of tracing the use of various web pages along with the recording and processing of pertaining data, web-designers of advertising firms and agencies cannot rely on authentic and exact research results "facilitating the elaboration of media strategies and concepts via calculations of coverage, frequency, and affordability" [4, p. 264]. There can be several explanations for this phenomenon: firms or advertisers maintaining home pages cannot always access user data, the identification of the visitor or homepage client is rather difficult, and the processing of available data requires special knowledge, whose application is not only time consuming, but poses a significant financial burden. Thus, management personnel do not require web page designers to adhere to the most important and best-known ergonomical conventions, and do not encourage the designers to customise the web pages to the respective user demands.

In summary, it can be concluded that one crucial aspect of the efficiency of on-line marketing communication is the improvement of the quality of web design. While this goal can be approached through the presentation of data used for traditional media design programs, by itself this information is not sufficient to improve an organisation's own on-line advertising campaign, or for the design and promotion of its web page.

\section{Subject, objective, and professional background of the present research project}

The present research focuses on a site where no trade or commercial activities take place, the users are not identified, and the access log data are available. The research concentrates on the homepage of the Eszterházy Károly College (www. ektf.hu) as used during a ten month time period in 2007. The institution in question has a public Internet site; extranet is not used, and certain tasks are accomplished through intranet systems. 
The current homepage, still available at the same URL address, differs from the one examined in this article. The homepage of the Eszterházy Károly College underwent a full structural, content and design renewal as of October 9, 2007. Apart from a few weeks of information recorded in the web-log, the digitally stored data examined by the present research span a time period from January 7, 2007, until the date of the restructuring.

The navigation system of a homepage is a basic component of on-line communication. The navigation features not only provide reliable orientation for the client but contribute to the promotion of the appropriate organisational image. The present research effort aims to identify the design errors that impacted auxiliary and support equipment and search features. The exploration of the respective shortcomings is expected to lead to new conceptual approaches for restructuring the particular homepage while eliminating or reducing cognitive dissonances.

Hypothesis 1: During the design process of the four main features of webpage navigation including the logo, menu points, utilities (auxiliary materials), and position indicators conventions based upon ergonomical research were not taken into consideration.

Hypothesis 2: The search engines are not adaptable to user behaviour and conduct while the principle of semantic grouping and disjunctive design is not fully observed.

The textual references appearing below indicate the following dates:

Period A: examination period 1, 2007. January 7-February 4.

Period B: 2006/07. Semester II., 2007. February 5-May 18.

Period C: examination period 2, 2007. May 19-June 30.

Period D: summer holiday, 2007. July 1-2007. August 20.

Period E: 2007/08. Semester I.: 2007. August 21-2007. October 9 .

\subsection{General and ergonomic requirements for components determining navigation capability}

While the most conspicuous and indispensable element of any navigation structure is the menu system, other components also contribute to the process. At the beginning page of a site the following five conventional components define web-based navigation:

$-\log 0$

- respective menu points,

- sub points,

- utilities (auxiliary features), and

- position indicators (graphic or textual elements indicating actual position).
In addition to the above-mentioned navigational elements the site includes the name of the webpage, local navigation features, and text-based menu points mostly located at the bottom of the web page. Constant and global navigational components denote features available at all pages of the given site [14, p. 60]. This examination concentrates on four items of the five main features, the logo, the menu points, the utilities, and the situation indicators.

An important part of the elaboration of any organisational image is the achievement of a unique profile or Corporate Identity. Thus the logo and the visual presentation of the homepage can play a significant role in this process (PR devices [17, p. 242]). In addition to guaranteeing the stability of navigation, the right emblem or logo can promote consumer or client confidence in the given organisation. During the elaboration of the logo the following guidelines should be observed: the logo should be placed on all pages of the site, and by clicking on it the client should be able to return to the starting page. The logo placed on the starting page should differ from those of located on the rest of the site in order to accentuate the respective function in a visual manner. The logo should be either placed near or on the top of the left side of the web page as it fully represents the whole homepage for the user, in addition to being the summit of the logical hierarchy of the homepage. Furthermore, the logo should be graphically recognisable and should be prepared with unique features, colours, and characters [14, p. 73].

The main menu located on the beginning page and other pages of the well-designed site is the most important menu group of the homepage. The most crucial segment of the main menu is the menu points, while the subordinated menu components are called submenu points. Ergonomical research suggests adherence to the following menu design principles: semantic grouping, total presentation, disjunctivity, and the use of terminology familiar to the user. Semantic grouping is based on the similarity and connections between the respective menu points. According to the principle of totality, menu points should cover all options available in the respective user context and disjunctivity assures the elimination of overlaps between menu points [1, p. 90]. Additional important menu design criteria include the depth and width of the menu. The depth of the menu, that is, the number of the levels cannot exceed 3 or 4 , and the width of the menu points should not include more than 6-8 items. The latter component is related to the 5-9 capacity of the work memory only applicable to occasional clients, as professional users are capable of navigation and orientation in more menu points than this [1, p. 89].

The general guidelines and principles elaborated for the design and preparation of menu systems are complemented with utilities (auxiliary devices) of similar appearance. These utilities are a visually homogeneous and cohesive collection of references related to the crucial points of the homepage, yet not closely associated with content-based ranking or hierarchy. Utilities fulfil a dual role supporting web page use and providing 
information. Compared to the components of the menu system utilities must have a simpler appearance, should not include more than 5 elements, and must present only the most important information for users [14, p. 75].

The search engine function can appear either in the utility category or as a separate special field. Research efforts concerning on-line communication habits emphasize user search preferences over browsing. A significant portion of home page users wish to proceed further with the key word searching feature consisting of a click icon or button and the term "search," of the given home page. During the design effort the following guidelines should be adhered to: the term "search" should not be modified, and no instructions should be provided to narrow down the scope of the search. It is important to provide a general focus of the search, but not to supply a selection option for content (article number, firm or product name, book title, author, faculty, department etc.) because the resulting excess work will significantly decrease the number of successful potential hits. Yet, in special cases, the inclusion of options specified according to the location of the search (web page, site, full web search) is acceptable [14, p. 75].

The graphic or textual indication of the actual position, or an indicator better known in the real world as "you are here" is an effective antidote to misorientation or against losing one's way in the World Wide Web. In lieu of perceiving space and distance in the virtual hierarchy, the securing of menu points and subpoints for the visitors is imperative, in addition to the logo. Although efforts striving for elegant design prefer the inclusion of this element among the rest of the features, a positioning point can only provide a sense of security if it can be clearly distinguished. Thus, in order to highlight the position indicators or markers, more visual features should be utilised [14, p. 84].

In addition to the position markers discussed above, breadcrumbs and tabs should be mentioned. While these components are frequently found in navigation systems, their use is not compulsory. A breadcrumb represents the actual elements of the hierarchic system of the full homepage. It should be located in the top row of the webpage listing in small print the menupoints chosen by the user while using a separator sign: "> ". Although not considered a position marker, the term "you are here" is often placed in front of the listing. Tabs provide a clearly defined and elegant navigational device for all users. Tabs have to meet three ergonomic requirements: the realistic drawing or design, consistent use of colours, and the promotion of inherent interpretation and understanding [14, p. 86].

\subsection{Webmining as a research tool}

Webmining is part of business intelligence, and provides decision-making support for management. In webmining, through an iterative process consisting of intelligent operations and operational sequences, certain data patterns are separated from (often) unstructured data piles. Intelligent operations include various statistics based analytical approaches such as neu- ral networks and factor analysis. Although webmining uses the elements of statistics, its sophisticated mathematical and informatics foundation surpasses the boundaries of that discipline [7]. At the end of the process new knowledge is obtained, heretofore unattainable with current database technology devices [15].

Webmining often confronts such difficulties as the excessive amount of data on the Web, the unstructured nature and complexity of web pages, dynamically changing web pages, and the identification anomalies of users. Accordingly, webmining entails three main tasks: web content mining, web structure mining, and web usage mining [7]. Web usage mining, of the greatest interest to this study, reveals the habits and behaviour patterns of users. Web usage mining can also be considered web $\log$ mining as well since today it is mostly based on the weblogs prepared by web servers. The analyses related to the present essay were performed by web usage mining tools.

In web usage mining, the online activities of an unidentifiable user are recorded. The data collection effort is completed when the visitor leaves the homepage; thus, for each visit, the person is considered a different user. Consequently, the resulting large number of visitors provides a large body of data. Analysis combines these data, creating information profiles that may be useful for web page-related decisions of marketing management.

\section{The analysis}

Clay Shirky, a professor of New York University put forth an acceptable, yet unproven info-communicational hypothesis. Shirkey believes the amount of all available information is always constant and identical and the only reason that we feel overwhelmed by information is that unlike in earlier times information filters are not functioning satisfactorily today [6, p. 7]. Appropriate filtering mechanisms, which evolve in a given society operating at a respective technological level, have not yet fully developed in the world of the Internet. Since the emergence of a complete data filtering system cannot be expected in the near future the analysis of web data is indispensable for organisation executives and decision makers.

Navigation and search features provide a sort of straining or filtering capacity and help orient users in the midst of seemingly limitless data. Users do not like to browse through homepages that do not observe ergonomic conventions, and feel hindered by visual or content-based elements. Although the navigational feature of a given homepage is based on numerous elements, the present examination is focusing on the most important components, especially, those on the beginning page.

\subsection{The ergonomic criteria of elements determining navi- gation capability}

According to research results the following five conventional elements determine navigation on the web: the respective logo, the menupoints, the submenu points, utilities and graphic or textual position markers [14, p. 60]. While a part of the examina- 
tions are concluded during the test run of the homepage, the more detailed analyses require the use of webmining tools.

\subsubsection{The logo and the menu points}

As Fig. 1 indicates the logo fulfils its function by being clearly distinguishable from other elements of the given homepage. It is clearly recognizable on the site and it is appropriately placed in the top left corner. The only shortcoming is that the user has to click the icon several times to facilitate a return to the starting page. Furthermore, due to the identical appearance of the logo on each page, one of the basic conventions, that is, distinctive appearance for the starting page logo, was not observed.

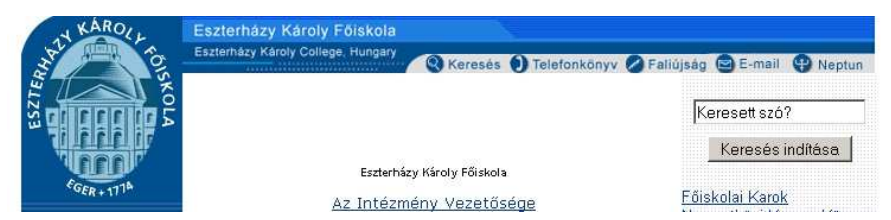

Fig. 1. The logo of the web-page as a navigational element placed in the top left corner

Since the results of the web-mining analysis of the respective menupoints have already been published [3], only a brief summary is included here. The webmining effort yielded no evidence of menu system-provided support. Since the restructuring effort did not take into consideration user behaviours, or design guidelines, a significant modification of the menu system is recommended. Moreover, the placement, interaction, and definition of the menupoints were also problematic, as evidenced by violations of semantic grouping and disjunctivity principles. With the exception of the principle of totality, the site demonstrated no adherence or fulfilment of recommended design criteria.

\subsubsection{Utilities}

As Fig. 2 indicates the utilities of the home page in question are always identically placed in the top row. The utilities navigational element is always separate from the menu system, and the number of the elements is five, not exceeding the pre-determined upper limit.

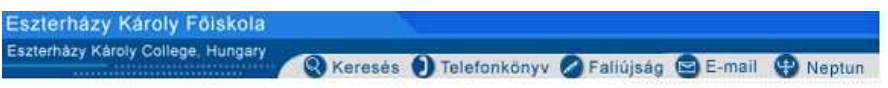

Fig. 2. The utilities of the examined home page

However, problems and shortcomings in both visual and content-based aspects can be identified. The utilities feature appears to be much more emphasised as compared to the menu segment. A more modest and restrained appearance can be achieved by the omission of graphic elements before the navigational components. As far as content is concerned, justified by the overall user need, the Search, Telephone Book, and Neptun elements are properly highlighted. The same, however, cannot be stated about the Bulletin and E-mail section. The Bulletin feature had low usage; it is likely the required registration discouraged a wider participation. The E-mail segment facilitated employee access to a web-based communication system via mailboxes identified with the domain name of the organisation. Most users, however, communicate via a client mail program, and a large section of users cannot take advantage of this feature. The inclusion of these features in the utilities segment is, thus, not justified. The examination concluded that the design principles pertaining to utilities were not fully observed.
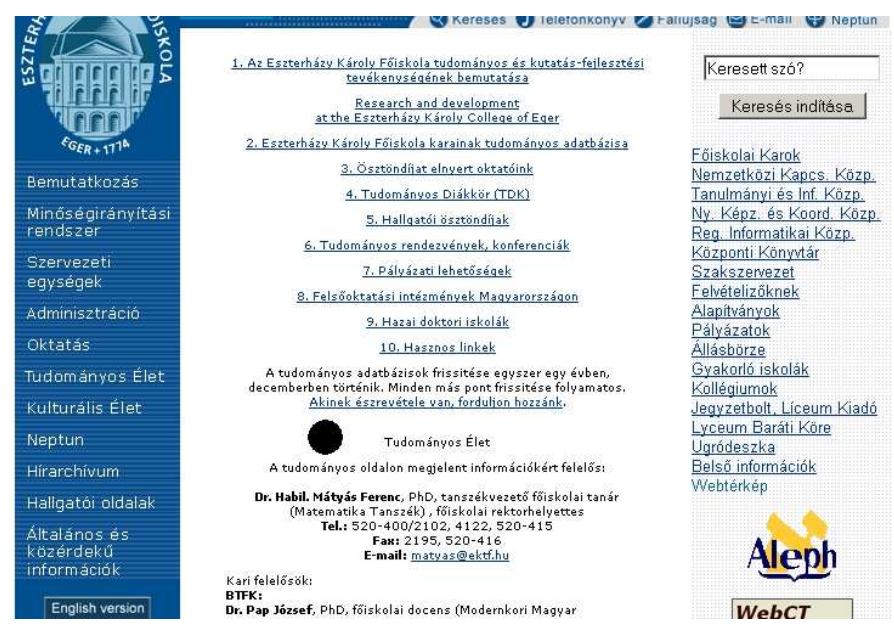

Fig. 3. Position markers missing from the home page

\subsubsection{Position markers}

The web page design effort did not pay full attention to position markers, as the actual positions are not indicated. The "you are here indicator" could have marked the chosen menu point with a different colour, or by an arrow pointing towards its direction, but the left side menu remains unchanged after the selection process. While on Fig. 3 we selected the Scientific Activities (Tudományos Élet) menu point, there is no evidence of the choice on the homepage. Furthermore, the Scientific Activities section, printed in black and intended for placement on the left side, is, instead, located in the middle of the page. Thus, this menu point has no navigational role since it does not visually emphasize the character and type of the very term on the left side. Furthermore, no return feature is available, and the text of some titles is not identical with the menupoint selected from the left side. Therefore, it can be concluded that the position marker does not help, but prevents the user from efficiently operating the site. The lack of chosen lists or breadcrumbs is a significant design error because the depth of the menu structure exceeds three levels. The examination of the logo, the menu points, the utilities, and the position markers substantiated hypothesis 1 , and proved the design conventions were not observed in any stage or component of the navigation process.

\subsection{Examinations based on the searching habits of users}

Search as a navigation element is a favourite client tool, not requiring significant intellectual effort. An exploration of searching habits of the home page visitors was conducted. 


\begin{tabular}{|c|c|c|c|}
\hline \multicolumn{4}{|c|}{ Number of visits starting with Homepage then Search } \\
\hline \multicolumn{4}{|c|}{$\%$ of Visits Starting With Homepage Then Search } \\
\hline \multicolumn{4}{|c|}{0.16} \\
\hline \multicolumn{4}{|c|}{ Total Occurences Of Homepage To Search Anytime During The Visit } \\
\hline \multicolumn{4}{|c|}{226} \\
\hline \multicolumn{4}{|c|}{ Number Of Visits With At Least One Homepage To Search Sequence Anytime During The Visi } \\
\hline & & & 211 \\
\hline \\
\hline \multicolumn{4}{|c|}{$\begin{array}{r}\% \text { Of Visits With At Least One Homepage To Search Sequence Anytime During The Visit } \\
0.22\end{array}$} \\
\hline Name & Long name & Storage & Value \\
\hline homepage_event & & ? (Unknown) & Homepage \\
\hline search_event & & ? (Unknown) & Kereses \\
\hline
\end{tabular}

Fig. 4. Searching habits of visitors (on the left side: Examination period 1. 2006/2007. January, on the right side 2006/2007. semester II.)
First, the research effort attempts to assess the professionalism of the web users. Fig. 4 compares use of the search option by visitors in two periods. In the academic or study period of the second semester of the 2006/2007 academic year (2006/07. II: $0,22 \%)$ more people used the search function than in January, the examination season of the same period (examination period 1: $0,95 \%)$. The rate of the searches still remains under $1 \%$, which could be interpreted in two ways. By the later time period, clients may have acquired skills in using the menu of the homepage, thus, they do not perform searches. Alternatively, clients, for some reason, do not prefer the search function. However, the first interpretation appears valid, as by the time of the survey most students and teachers had been spending their second semester in the institution, thus they could be considered professional home page users. The relatively low rate of immediate searches (Fig. 4) compared to all homepage visitors (examination period 1: $0,16 \%$, or 2006/07. II: 0,79\%) presupposes a large number of experienced users.

As Fig. 5 indicates search functions are available in two places, with use of a menu point and through a type-in field. Both options can be found in the upper menu line.

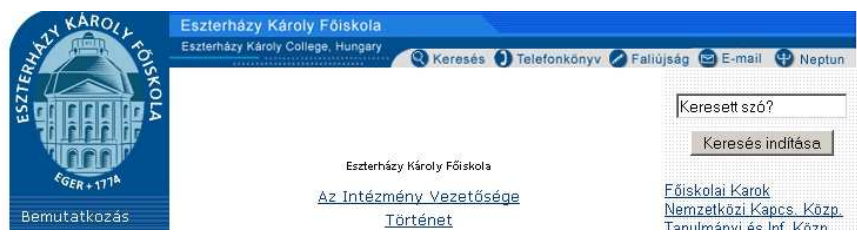

Fig. 5. The search menu point of the upper menu line with the type-in search field beneath

Visitors, considered professional by the marketing management with an acceptable margin, can utilise more than one search function feature. Table 1 includes the number of menu and field selections at the given periods. Almost $80 \%$ of the visitors utilise the search field for that purpose, and during the examination period the rate of the search is greater. Yet, if we do not consider the beginning weeks of the academic year, the rate of searches projected for one week in the examination period is the highest in the whole term. The principle of semantic grouping is violated in the search options. The names of the two search options are identical, which, in the case of so closely placed elements, is misleading. Apart from the beginning step, the search menu point and the type-in search field do not have
Number of visits starting with Homepage then Search

0.79

Total Occurences Of Homepage To Search Anytime During The Visit

942

Number of Visits With At Least One Homepage To Search Sequence Anytime During The Visit

\begin{tabular}{|c|c|c|c|}
\hline \multicolumn{4}{|c|}{$\%$ Of Visits With At Least One Homepage To Search Sequence Anytime During The Visit } \\
\hline Name & Long name & Storage & Value \\
\hline homepage_event & & ? (Unknown) & Homepage \\
\hline search_event & & ? (Unknown) & Keres_mezo \\
\hline
\end{tabular}

Keres_mezo
$\%$ of Visits Starting With Homepage Then Search

different functions. This practice thereby leads to inadequate adherence to the principle of the disjunctivity of the elements. Consequently, hypothesis 2 is substantiated.

According to the analysis (2006/2007. II.) users performing the search function, and those selecting the foreign language page, comprise a significant segment, accounting for almost $10 \%$ of all visits. The selection of the English version and the fixed place for the choosing of the search function are rather far from each other. The former is the last still image-based menu point on the left side (Fig. 3), while the search function is in the upper menu. While the principle of semantic grouping is violated, the designers could not have anticipated such problems. Without web mining examinations such shortcomings cannot be discerned; thus hypothesis 2 can be substantiated as well.

\section{Summary}

The analyses prove without the examination and monitoring of designers and users, or merely by the instinctive guidance on the part of management, no web page can be customised to user demands. This goal can only be achieved with the gradual restructuring of the homepage. Relying on instinct and experience on the part of the marketing management is not only insufficient, but rather misleading, and cannot substitute the consistent application of appropriate design principles.

Compared to traditional communication, the analysis of online communication has to take specific requirements into consideration. The conventions of ergonomic research can be used, but other research efforts and the present analysis have demonstrated that this objective has not significantly impacted marketing management strategy. Fields of study for the preparation of executive decision-making sooner or later will include the analysis of communication towards on-line clients. In order to meet the criteria of competitiveness more attention is expected to be paid to this issue.

\section{References}

1 Antalovits M, Izsó L, Bevezetés az információ-ergonómiába 1. sz. tanszéki példány (Introduction to information ergonomy Departmental copy No. 1), 2000.

2 Agent Portal, Videokonferencia a virtuális térben (Video conferencing in virtual space), (August 2007, 27). http://www.agent.ai.

3 Bóta L, Azonosítatlan felhasználók szokásai egy oktatási intézmény honlapján. Oktatás-innováció és minöségfejlesztés az IKT stratégiai integrálásá- 
Tab. 1. Visitor searches in the examined period performed with the help of the search menu and search field

\begin{tabular}{lcccccc}
\hline & $\begin{array}{c}\text { Period A } \\
\text { total }\end{array}$ & $\begin{array}{c}\text { Period B } \\
\text { (exam. }\end{array}$ & $\begin{array}{c}\text { Period C Period D } \\
\text { (2006/07. }\end{array}$ & $\begin{array}{c}\text { Period E } \\
\text { (exam. }\end{array}$ & $\begin{array}{c}\text { (summer } \\
\text { (2007/08. }\end{array}$ \\
& \multicolumn{2}{c}{ (20) $)$} & Semester II.) & period 1) & holiday) & Semester I.) \\
\hline Search menu & 10283 & 1620 & 2688 & 2596 & 1215 & 2164 \\
Search field & 48449 & 7209 & 8793 & 13673 & 6593 & 12181 \\
Menu + field together 58732 & 8829 & 11481 & 16269 & 7808 & 14345 \\
Number of weeks & 4 & 11 & 6 & 7 & 6 \\
Weekly average & 2207 & 1044 & 2712 & 1115 & 2391 \\
\hline
\end{tabular}

val (Unidentified user habits and activities on a homepage of an educational institution. Educational innovation and quality improvement with the integration of ICT strategies), BME-APPI Konferencia (BME-APPI Conference) (2008).

4 Brochand B, Lendrevie $\mathbf{J}$, A reklám alapkönyve (Introduction to Advertising), KJK-KERSZÖV Jogi és Üzleti Kiadó Kft. (Legal and Business Publishers), 2004.

5 Eszes I, Bányai E, Online m@rketing, Múszaki Könyvkiadó, Budapest, 2002.

6 Gerhardt E, Ismeri önt az internet? (Does the Internet know you?), Computerworld. Számítástechnika. ICT-stratégia döntéshozóknak, 39/48, (2008).

7 Han J, Kamber M, Adatbányászat. Koncepciók és technikák (Web mining: Concepts and Technologies), Panem, Budapest, 2004.

8 Kelenhegyi P, Vállalati honlapok. A Bell Research Magyar Infokommunikációs Jelentése alapján (Homepages of business enterprises according to the Bell Research Hungarian Infocommunication Report), ITbusiness, 2008/3, (2008).

9 _ Vállalati honlapok. A Bell Research Magyar Infokommunikációs Jelentése alapján (IT development in the public sphere according to the Bell Research Hungarian Infocommunication Report), ITbusiness, 2008/22-23, (2008).

10 _ Intézményi internetpenetráció. A Bell Research Magyar Infokommunikációs Jelentése alapján (Institutional interpenetration according to the Bell Research Hungarian Infocommunication Report), ITbusiness, 2008/3031, (2008).

11 _ Intézményi honlapok és e-ügyintézés. A Bell Research Magyar Infokommunikációs Jelentése alapján (Institutional homepages and eadministration according to the Bell Research Hungarian Infocommunication Report), ITbusiness, 2008/32-33.

12 _ Internet a cégeknél. A Bell Research Magyar Infokommunikációs Jelentése alapján (Internet in the business world. According to the Bell Research Hungarian Infocommunication Report), ITbusiness, 2009/12, (2008).

13 Kotler P, Keller K L, Marketingmenedzsment (Marketing management), Akadémiai Kiadó, Budapest, 2006.

14 Krug S, Ne törd a fejem! Felhasználóbarát webdizájn (Do not rack my brain! User-friendly web design), HVG, (2008).

15 Információból üzleti érték. Az információbróker környezete és munkája. Magyar Információbrókerek Egyesülete (Information as a business asset. The environment and work of information brokers. The Association of Hungarian Information Brokers), (2006).

16 Nilsen J, Web-design, Typotex, 2002.

17 Vágási M, Marketingmenedzsment - stratégia és menedzsment (Marketing management principles: strategy and management), Alinea Kiadó, 2007. 